\title{
The Growth of Lactobacillus fermentum Isolated from Quail Intestine on Rice Bran Medium
}

\author{
U. Kalsum ${ }^{*}$ and O. Sjofjan ${ }^{2}$
}

\author{
${ }^{1}$ Faculty of Animal Husbandry, Islamic University of Malang, East Java, Indonesia. \\ ${ }^{2}$ Department of Animal Nutrition, Faculty of Animal Husbandry, Brawijaya University.
}

\begin{abstract}
The objective of this study was to investigate the growth of Lactobacillus fermentum isolated from the intestine of Japanese quail (Coturnix japonica) on medium of rice bran meal. The influence of this medium on the cell growth of $L$. fermentum and its lactic acid product were evaluated every six hours for 36-hours incubation. A randomized block design was used to assign three variation of rice bran medium (6; 9 and 12) \%. The result showed that $9 \%$ of rice bran medium showed the best medium for L. fermentum growth, the cell number reached $5.2 \times 1010 \mathrm{CFU} / \mathrm{mL}$ and lactic acid concentrations 0.57 $\%$ for 12 hour incubation ( $\mathrm{pH} 4.7$ ). We concluded that the optimum growth of L. fermentum was in $9 \%$ rice bran medium at 12 hour.
\end{abstract}

Keywords: Lactobacillus fermentum, growth, quail, rice bran.

\section{INTRODUCTION}

Product of Japanese quail (Coturnix japonica) i.e. egg and meat have a high potential to be developed as a cheaper source of protein, especially in developing countries. In recent years, with growing family incomes, the demand for poultry products has increased in Indonesia. At the same time, consumers are also becoming increasingly concerned about the safety of poultry products. The major concerns are related to the presence of antibiotic residues in poultry products that can cause adverse effects on human health and the possible development of antibiotic resistant bacteria. One key strategy to replace the use of antibiotics in poultry diets is application of probiotic in poultry feed, which are known to exert beneficial effects in the gut, directly to the bird. Probiotics are live microo rganisms which are supplemented to the feed in order to establish as beneficial gut micro flora. Use of these microbes in diets for Japanese quail may enhance the intestinal health by modifying the gut micro flora. Probiotics not only deliver health benefits for the birds that consume them,

\section{*Corresponding address:}

U. Kalsum

Faculty of Animal Husbandry, Islamic University of Malang, Jl. Dinoyo, Malang, East Java, Indonesia.

E-mail: kalsum2008@gmail.com but also for consumers who purchase the poultry products. In our laboratory, several strains of microbes have been success-fully isolated from the intestinal tract of quails and characterised [1]. The microbial from genus of Bacillus was selected for evaluation as a probiotic. The genus is known to produce several enzymes such as protease [2] and amylase [3] and therefore it potentially can be exploited as a pro-biotic. The bacteria was identified as Lactobacillus fermentum that promising for probiotic [1]. The spore-forming of the bacteria are stable, resistant to high temperatures and tolerant to bile salts.

Rice bran is animal feed that contain the high concentration of vitamin $\mathrm{B}$, tocopherol, $74 \%$ unsaturated fatty and complete amino acid that is the highest compared to other cereals [4]. Soluble fiber content within rice bran is good nutrition for the growth of lactic acid bacteria (LAB) such as Lactobacillus fermentum. The character of LAB from the digestive tract of quail can be affected by the condition of the digestive tract and the feed [5]. The quail feed became a source of organic material for the growth and metabolism of LAB in the digestive tract. Nutrients for the growth of Lactobacillus can be derived from the host feed and other organic matter in the digestive tract. Therefore we evaluated effect from various concentrations of rice bran mediums on growth of Lactobacillus fermentum. 


\section{MATERIALS AND METHODS}

The experimental protocol was approved by the Brawijaya University Animal ethics and welfare Committee. L. fermentum was isolated from the intestine of Japanese quails and cultured in agar based on the formulations of deMan, Rogosa and Sharpe (MRS) for 48 hours at $37^{\circ} \mathrm{C}$. This medium supports growth of lactobacilli from oral, fecal, dairy, and other sources [6]. Then a series dilutions up to $10^{-7}$ in MRS liquid was performed, followed by spreading on MRS agar that containing $60 \mathrm{mg} / \mathrm{kg}$ Bromocresol purple (BCP) and incubated for 24 hours at $37^{\circ} \mathrm{C}$. Lactic acid bacteria (LAB) colony was counted based on the change of media to be pale yellow at the location of the growth of bacterial colonies. The characteristic test confirmed that the isolates are $\mathrm{LAB}$, gram positive, catalase negative and negative endospores. Isolation of the species was confirmed with the API $50 \mathrm{CH}$ test Medium Kit $[7 ; 8]$ and API 50 CHL medium.

To determine it's feasibility as a probiotic, the candidate was then evaluated using several tests, including $\mathrm{pH}$ test, pathogen test and bile salt test. Rice bran as medium was weighed $(\mathrm{g} / \mathrm{v})$ to accordance three concentration $(6 \%, 9 \%$ and $12 \%$ ), and then dissolved in aquadest and heated at $85^{\circ} \mathrm{C}$ for 10 minutes. One $\mathrm{mL} \mathrm{(v/v)} \mathrm{isolates} \mathrm{of}$ BAL $\left(10^{7}\right.$ cells $\left./ \mathrm{mL}\right)$ was inoculated into $10 \mathrm{~mL}$ rice bran medium $(6 \%, 9 \%$ and $12 \%)$. The speed of growth and the generation of time on the logarithmic phase were calculated with the formula of [9]. A Randomized block design Group was used to assign three variation of rice bran medium (6, 9 and 12) \%. Some Variables were observed every six hours for 36 hours of incubation including total lactic acid bacteria, acid levels and the $\mathrm{pH}$ of media. Data were statistically analyzed using the analysis of variance. Significant differences between treatment means were separated using Duncan's multiple range test according to [10].

\section{RESULTS AND DISCUSSION}

\section{The characteristics of rice bran}

The chemical analysis of rice bran shows that the $\mathrm{N}$-amino acids levels of $0.43 \%$ and total sugar levels of $0.85 \%$. According to [11] that the rice bran protein is $14 \%$ and the carbohydrates is $36 \%$. The chemical composition of rice bran depends on genetic factors, environmental influences, and the conditions of storage.

\section{The growth of Lactobacillus fermentum}

The growth curve of Lactobacillus fermentum in media MRS broth (prior to inoculating in the rice bran medium), reaching the higest cell number was at 22 hour. While in $12 \%$ rice bran medium, the maximum cell number was at 18 hour of $10.66\left(\log 10\right.$ of $\left.7 \times 10^{10} \mathrm{cfu} / \mathrm{mL}\right)$, on $9 \%$ rice bran medium at 12 hours of 10.58 and in $6 \%$ rice bran medium at 18 of 10.3 . This shows that the growth of Lactobacillus fermentum more optimum on $9 \%$ rice bran medium due to more quickly reach the log phase (Figure 1) than in media rice bran $12 \%$ or $6 \%$. The addition of substrate will be able to accelerate the speed of reaction until the maximum speed is reached when the enzymes are saturated. After that the addition of substrate will not be able to increase the speed of reaction. According to [12] enzymes will effectively work on conditions determined by the concentration of substrate, $\mathrm{pH}$, temperature and cofactors.

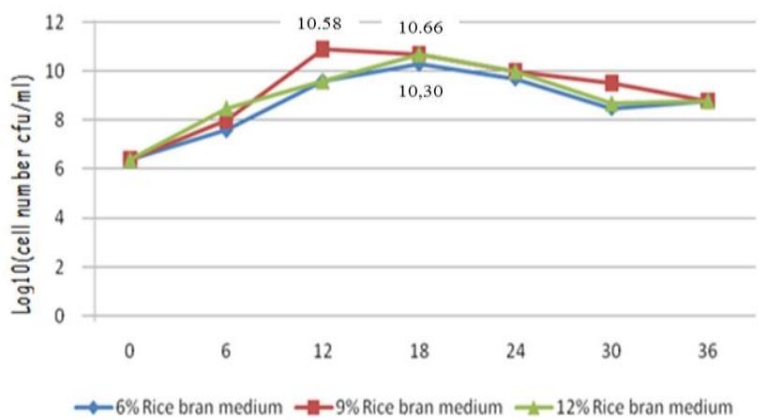

Figure 1. Growth rate of Lactobacillus fermentum

Table 1. Generation time of Lactobacillus fermentum ${ }^{1}$

\begin{tabular}{|c|l|l|}
\hline \multicolumn{1}{|c|}{ Medium } & Generation $(\mathrm{h})$ & $\mathrm{k}($ generation $/ \mathrm{h})$ \\
\hline $6 \%$ rice bran & $1.33^{\mathrm{a}}$ & $0.52^{\mathrm{a}}$ \\
\hline $9 \%$ rice bran & $0.75^{\mathrm{b}}$ & $0.92^{\mathrm{b}}$ \\
\hline $12^{\%}$ rice bran & $1.70^{\mathrm{a}}$ & $0.40^{\mathrm{a}}$ \\
\hline Pooled SEM & 2.078 & 1.440 \\
\hline
\end{tabular}

k: ln 2/generation time (constant of growth speed).

a,b Different superscripts in a column denote significant difference $(\mathrm{P}<0.05)$.

${ }^{1}$ Each value represents the mean of four replicates.

At the 24 total LAB on all media treatment decreased and in 30-36 hours they reach stationary phase. The result is different from research of [13] that the growth of commercial probiotic, the highest cells number at 12 hour in $12 \%$ rice bran medium.

Figure 2 shows that the highest rate of growth occurs in $9 \%$ rice bran medium with constant of growth speed of 0.92 generation/h and generation time 0.75 hour. The cells number of bacteria in the rice bran medium was significantly different at each incubation time. 
Nutrients composition of rice bran able to increase the growth activity of Lactobacillus fermentum especially soluble fiber content of $12 \%$ as well as all the essential amino acids, vitamins B complex, vitamin C, D and minerals such as calcium, phosphate and irons. Vitamin B is the main component of coenzyme that can help to activation the enzymes of microbial cells [14] so that they can accelerate the growth of bacteria.

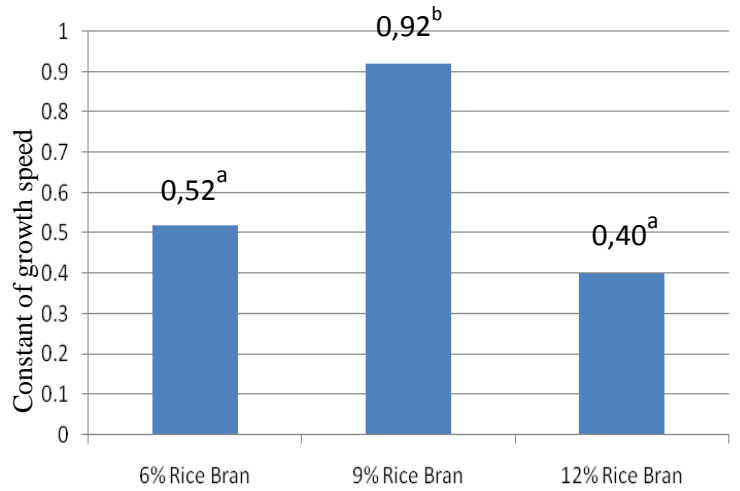

Figure 2. Growth rates of Lactobacillus fermentum

\section{The pH of Medium}

When bacteria cells are growing, they will produce organic acid due to $\mathrm{pH}$ of medium decline. Lactic acid produced by the LAB will be excretion out of cells and will accumulate in the fermentation media (substrate) that would increase the acidity.

The curve shows that at first to18 hour, the $\mathrm{pH}$ of treatment medium were significant decline because of Lactobacillus fermentum activity high enough. While at the 24 to 36 hour Lactobacillus fermentum began decreased activity. This corres ponds to the growth of bacteria cells, at first to18 hour, bacterial cell growth is high and at the 24 to 36 bacteria growth was decreased. According to [14] that incubation temperature optimum leads the process of ionization lactic acid into maximum resulting in increasingly large $\mathrm{H}^{+}$ion are exempt, so the $\mathrm{pH}$ decreases.

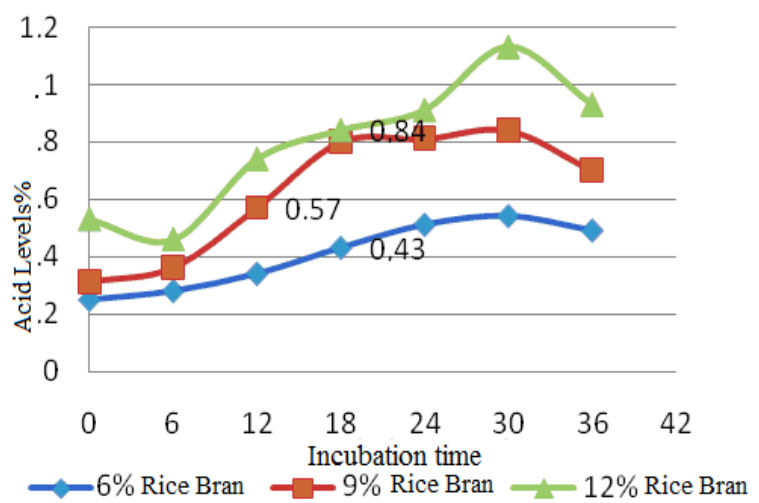

Figure 3. Changes rice bran medium $\mathrm{pH}$

\section{Acid Levels}

During the fermentation, LAB breaks down carbohydrates into simple sugar especially glucose and produce lactic acid as energy for cellular activities [15]. Based on the data, lactic acid levels increased from first to 30 hour and then decreased at 36 hour. The highest levels of lactic acid in the treatment is in $12 \%$ rice bran medium whereas the lowest levels in $6 \%$ rice bran medium. According to [16], the process of cell growth is accompanied by the formation of metabolite in lactic acid resulting from an overhaul of the sugar, proteins and other acids. In addition, the soluble fiber components can be used as a source of rice bran food prebiotic.

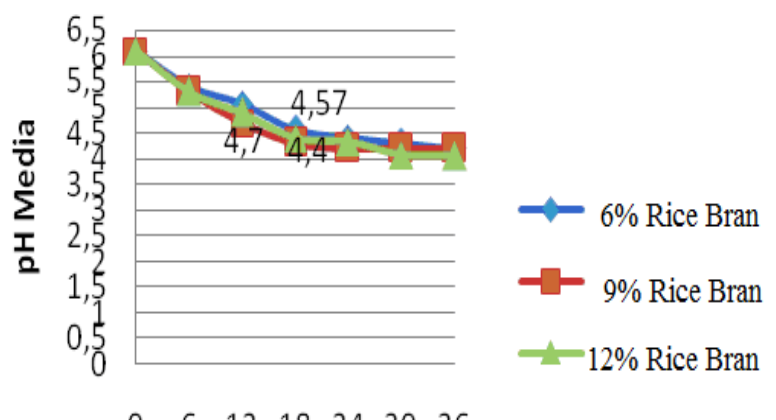

\section{Incubation Time}

Figure 4. Changes of acid levels in rice bran medium

The acid levels in rice bran medium had significant difference this is in accordance with the number of bacteria cells was significantly different so that affect acid levels. According to [17] that measurement of the $\mathrm{pH}$ is a concentration of $\mathrm{H}^{+}$ions in form dissociated so that not all components of acid measured. Total measurable titrated acid is categorized into dissociated and associated to overview NAOH binding.

\section{CONCLUSION}

The optimum growth of Lactobacillus fermentum was in rice bran medium $9 \%$, where Lactobacillus fermentum reached log phase at $\mathrm{pH} 4.7$ at 12 hour was $5.2 \times 10^{10} \mathrm{CFU} / \mathrm{mL}$ and $0.57 \%$ acid levels with constant speed growth of 0.92 generation/hour and time generation 0.75 hours.

\section{ACKNOWLEDGMENTS}

The authors are thankful to Professor Ir. Hendrawan Soetanto, M.Rur.Sc.Ph.D. Department of Animal Nutrition, Faculty of Animal Husbandry, Brawijaya University for his valuable comments in the preparation of this manuscript. 


\section{REFERENCES}

1. Kalsum U, O Sjofjan, D Suryanto \& Aulani'am, (2008) Proceedings international research seminar and exhibition on isolation, selection and characterization microbe from intestinal tract of quail as source of probiotic. Muhammadiyah Malang University. Indonesia.

2. Libertina I, A Tri, O Sjofjan \& U Kalsum (2009) Proceedings international research seminar and exhibition international symposia on the recent advances of microbiology in health, bio industry, agriculture and environment. Association of Microbiologist Indonesia (PERMI) Surabaya. Indonesia.

3. Wardhani WK, A Tri, O Sjofjan \& U Kalsum (2009) Proceedings international research seminar and exhibition international symposia on the recent advances of microbiology in health, bio industry, agriculture and environment. Association of Microbiologist Indonesia (PERMI) Surabaya. Indonesia.

4. Samli HE, N Senkoylu, H Akyurek \& AA Agma (2006) Using Rice Bran in Layer Diets. J Cent Eur Agric. 7(1):135-140.

5. Kalsum U, Hendrawan S, Achmanu \& Osfar S (2010) The Quality and Quantity of Japanese Quail's Eggs as Affected by Administration of Lactobacillus Fermentum. Proceedings International Seminar on Prospects and Challenges of Animal Production in Developing Countries in the $21^{\text {th }}$ Century. Organized by Faculty of Animal Husbandry University of Brawijaya Malang. March 23-25.

6. Murray PR, EJ Baron, MA Pfaller, FC Tenover \& RH Yolken (eds.) (1995) Manual of clinical microbiology. 6th ed. American Society for Microbiology. Washington DC.

7. bioMerieux (2001) API 50 CHL medium: Lactobacillus. http://courses.ag.uidaho.edu/fst/ fstmmbb417/api50_CHL_medium.pdf

8. Abegaz K (2006) Isolation, characterization and identification of lactic acid bacteria involved in traditional fermentation of Borde, an Ethiopian cereal beverage. African Journal of Biotechnology. 6(12):1469-1478.

9. Madigan MT, Martinko JM \& Parker J(2003) Brock Biology of Microorganisms. Tenth edition. Pearson Education Inc. London.

10. Steel RGD \& JH Torrie (1992) Principles and Procedures Statistics. Second Edition. McGrawHill. Singapore.

11. Cheruvanky (2001) What is Rice Bran. http:www.moormans.com/equine/tech Bulletins /what is Rice bran.htm.

12. Gauthier R (2007) The use of protected organic acids (Galliacid ${ }^{\mathrm{TM}}$ ) and a protease enzyme (Poultrygrow 250 ${ }^{\mathrm{TM}}$ ) in poultry feeds. Brochure of Alinat Colombia Ltda \& Jefo Latino America Ltda. April 23-26: 1-21.
13. Zubaidah E (2007) Exploration Isolate Lactate Acid Bacteria Probiotics Indigenous. http://prasetya.brawijaya.ac.id/des07.html.5.

14. Applegate TJ \& R Angel (2004) Phytase: Basic of Enzyme Function. Farm Animal Management at Purdue. Purdue University. Department of Animal Science. USA.

15. Aarnikunnas J (2006) Metabolic Engineering of Lactic Acid Bacteria and Characterization of Novel Enzymes for the Production of Industrially Important Compounds. Academic Dissertation. Department of Basic Veterinary sciences Division of Microbiology and Epidemiology University of Helsinki.

16. Adrizal S \& Ohtani (2002) Defatted Rice Bran Non-starch Polysaccharides in Broiler Diets: Effects of Supplements on Nutrient Digestibilities. J Poult Sci. 39: 67-76.

17. Biggs P \& CM Parsons (2008) The Effects of Several Organic Acids on Growth Performance, Nutrient Digestibilities, and Cecal Microbial Populations in Young Chicks. Poult Sci. 87: 2581-2589. 